\title{
DEER HERD MANAGEMENT USING THE INTERNET: A COMPARATIVE STUDY OF CALIFORNIA TARGETED BY DATA MINING THE INTERNET
}

\author{
G. Kent Webb, San Jose State University, g.webb@sjsu.edu
}

\begin{abstract}
An ongoing project to investigate the use of the internet as an information source for decision support identified the decline of the California deer population as a significant issue. Using Google Alerts, an automated keyword search tool, text and numerical data were collected from a daily internet search and categorized by region and topic to allow for identification of information trends. This simple data mining approach determined that California is one of only four states that do not currently report total, finalized deer harvest (kill) data online and that it is the only state that has reduced the amount of information made available over the internet in recent years. Contradictory information identified by the internet data mining prompted the analysis described in this paper indicating that the graphical information presented on the California Fish and Wildlife website significantly understates the severity of the deer population decline over the past 50 years. This paper presents a survey of how states use the internet in their deer management programs and an estimate of the California deer population over the last 100 years. It demonstrates how any organization can use the internet for data collection and discovery.
\end{abstract}

Keywords: Decision Support, Data Mining, Visualization and Internet Search

\section{INTRODUCTION}

Like many public and private organization, state wildlife agencies have increasingly relied on the internet to conduct business and to collect and distribute information $[1,5,9,15,22,24]$. The framework for deer management in the U.S. is summarized by this comment from a member of the California Fish and Game Commission in 1917, a year in which deer hunting was suspended to preserve the California herd. "In America the wild game belongs to the people in their sovereign capacity and is not subject to private dominion to any greater extent than the people through the legislature may see fit to make it [19]." Referred to as the North American model, decisions about large scale herd management are made by each state, through state agencies that typically invite public input. In 2012, Texas was the first state to move away from this model to include more private decision making. The first part of this paper provides a summary of internet applications being used by each state, such as selling licenses and reporting information about public hunting.

California was targeted for attention in this paper as part of an ongoing research project. A daily internet search has been conducted using Google Alerts and Google Search with keywords related to deer management since 2010. Information gathered this way is stored by region and topic in a searchable, website that is designed to provide decision support (www.DeerFriendly.com). Among the information systems issues being explored are: data mining and discovery, text search, data cleaning, contradiction analysis, online decision support, and the use of the internet as a data source. Some visitors to the open website have emailed describing how they have used the website to support their contribution to a decision making process. The decision support site has received over 60,000 unique visitors in the past year.

The second part of this paper describes how problems were discovered with the information on the California Department of Fish and Wildlife's website related to deer population trends. By overlaying data from different sources on a graph, large contradictions became apparent. In an effort to resolve the contradictions, historic deer population estimates were generated for the state of California over the past hundred years by using different assumptions for a reported kill to population ratio. This approach relies heavily on research published for the then named California Department of Fish and Game in 1952 by William M. Longhurst, one of California's most historically prominent wildlife researchers, and Aldo Leopold, considered by many to be the father of modern wildlife management. A test is conducted on the premise that a difference in reporting rates over time accounts for the apparent divergence in the estimated population and the reported number of deer killed by hunters. The test concludes that while there is a statistically significant difference between the average from 1990 to 2010 and the 


\section{Issues in Information Systems \\ Volume 14, Issue 2, pp.156-165, 2013}

number used for 1947, the difference in only about half a percentage point. The historic rate is within the range of the current rate. The difference is not enough to account for the significant divergence in the pattern of the historical reported deer kill and the historic deer population as currently estimated by the state of California. The people of the state are getting an inaccurate picture of the status of their deer from their deer managers. This example illustrates how combining several available tools can result in effective exploration of the internet.

\section{Data Mining the Internet}

Given the amount of data added to the internet each day, relying on the internet as a data source creates both a significant knowledge management challenge and opportunity. In a recent effort to address this problem, Bun [4] describes an "Emerging Topic System" designed to track information of interest to a particular user and to generate a summary of topics. Researches with Bassett describe an approach similar to the one used here that relies heavily on simple data classification and comparison. They warn that "...Data mining popular social networking sites by semiskilled malicious outsiders could piece together data elements which may give them an insider view on information [2]." Another data mining approach used in this study, examining independent data sources for reliability or conflicts, has been given a relatively new name, "Contradiction Analysis", defined as discovering when "...There is a contradiction on a topic, T, between two sets of documents ...[18]."

Also following a similar approach, a group of United Kingdom researches conducted a Google search for news stories on a particular topic and attempted to correlate related comments on social networks in order to help public decision makers understand public attitudes [17]. Yoon scans news topics related to solar energy to "identify weak signals that can affect the future business environment. Weak signals are defined as imprecise and early indicators of impending important events or trends [22]." Researches with Bhadoria designed a system that "detects major events by analyzing blogs using a novel clustering algorithm [3]." Researchers with Jockers comment on the potential limitations for data mining presented by current copyright legal battles that Google are engaged in [10]. Wu [20] describes how online news sites can adapt their design in HTML to support text and data mining. MacLean and Seltzer "propose that everyday, medically-oriented Web content is a valuable and viable data source for medical hypothesis generation and testing, despite its being noisy [14]." Researchers with Zimmerman "propose a text stream clustering method that detects, tracks and updates large and small bursts of news... [25]." Researchers with Xiang used searches of internet news articles to predict company acquisitions [21].

In 2011, the search conducted for this project picked up news trends about significant declines in the California and Nevada deer populations. There were also controversies over deer population models in Wisconsin and Nevada. An audit of Wisconsin's model concluded they were not accurate. The former Wildlife Commissioner for Nevada called their population models "wild guesses [8]." There were complaints in Nevada that deer harvest data was no longer being shared with the people of the state, on behalf of whom the Game Commission manages the deer. Mississippi stopped posting their deer harvest data online. California stopped posting final harvest data online in 2010. This prompted an investigation, summarized in the next section, about how the wildlife management agencies in each state are using the internet for deer management. Nevada currently has their harvest data up on their website, as well as their population model that can be accessed by any internet user. Mississippi has also posted their data. California posted only percentages by age class for bucks killed, no actual numbers, on their website. The harvest data was, however, sent to a Southern California bow hunter who posted it on one of their discussion websites, discovered through the internet data mining process.

\section{SURVEY OF WILDLIFE AGENCIES USE OF THE INTERNET FOR DEER MANAGEMENT}

Each state's website containing deer management information was examined on the internet. Table 1 reports a summary of the survey. Table 2 provides details. Most states, 46 out of 50, provide the annual total deer harvest data online. Of the states that don't, Hawaii has only a minimal deer hunt in the neighborhood of about 500 per year for the past twenty years. Almost all of the hunting occurs on private land in Hawaii. Although Kansas uses the internet to collect reported kills from hunters, provide hunting regulations, and keep track records for trophy deer, no harvest data is available online. Some data has been released to the press that can be found through internet search. North Dakota uses the internet less than any other state. The state sells hunting licenses online, but uses no social media and does not report hunting statistics online. 


\section{Issues in Information Systems}

Volume 14, Issue 2, pp.156-165, 2013

Table 1: Summary of Internet Uses by State Agencies for Deer Management (Details in Table 2)

\begin{tabular}{|c|c|c|}
\hline & $\begin{array}{l}\text { Number } \\
\text { of states }\end{array}$ & $\begin{array}{l}\text { Percent } \\
\text { of States }\end{array}$ \\
\hline Reports Total Harvest Data Online & $46^{*}$ & $92 \%$ \\
\hline Provides Data in Searchable Database Online & 10 & $20 \%$ \\
\hline Sells Hunting License Online & 50 & $100 \%$ \\
\hline Hunters Report Kills Online & 29 & $58 \%$ \\
\hline \multicolumn{3}{|l|}{ States Using Each Social Media } \\
\hline Facebook & 39 & $78 \%$ \\
\hline Twitter & 39 & $78 \%$ \\
\hline YouTube & 30 & $60 \%$ \\
\hline Flickr & 9 & $18 \%$ \\
\hline Google + & 5 & $10 \%$ \\
\hline $\mathrm{RSS}$ & 18 & $36 \%$ \\
\hline \multicolumn{3}{|c|}{$\begin{array}{l}\text { * Includes Hawaii which has a minimal deer harvest of about } 500 \text { per } \\
\text { year, mostly on private property. Other states are Kansas, North } \\
\text { Dakota (least use of the internet), and California which had been } \\
\text { reporting online, but which has posted only incomplete data since } \\
2010 \text {. }\end{array}$} \\
\hline
\end{tabular}

Online, searchable databases involve some substantial investment. As reported in Table 1, only 10 states, 20 percent of the total, provide this service. Some of these are small states with a significant tradition of deer hunting, such as Idaho and Montana. All 50 states have become engaged in hunting e-commerce, with 100 percent of states selling hunting licenses online and some providing detailed information with regard to drawing statistics. California recently developed an online sales and reporting system. Since demand for deer hunting licenses (deer tags) often exceeds supply, a lottery approach is often used by states rather than the politically unpopular alternative of increasing license fees. Many hunters rely on deer harvest statistics to plan their strategy to win a license. Most of the states, 29, allow hunters to report their deer kill online. This data is often used to assist in management such as estimating deer populations. Some states do not require hunters to report their kills and rely on survey data for management information.

As reported in Table 1, Facebook and Twitter are tied at the top for use in social media with 39 of the states using each of these social media. The use of Twitter has particularly increased recently. YouTube is the next most used social media tool, with 30 states having YouTube channels or content. Some states such as Wisconsin and Vermont have made particular use of YouTube by provided video recordings of planning meetings where the public is invited to attend and participate in the planning process. California does not use YouTube for this application, but does provide video recordings of the game commission planning meetings where the public is invited to attend and participate in the management of deer and other game animals.

Most states provide a news page to keep their residents up to date, but only 18 use RSS to distribute news. Only 9 states use Flickr to share photographs. The least used social media on the list was Google +1 with only 5 states deploying this social utility. Traffic on the Twitter feeds far exceeded Google +1 . Details of the states use of internet tools appears in Table 2.

Many states encourage citizen participation in managing their herd. For example, Wyoming citizens are invited to participate in annual deer counts. In Wisconsin, Operation Deer Watch encourages hunters and others observing deer to enter their observations through an application on the Department of Natural Resources web site. Volunteers have offered to provide support in helping count the California black-tail deer population, notoriously hard to count since their habitat often includes dense forest, but during the March 6, 2013, California Big Game Commission meeting, Michael Kobseff, Sikiyou Board of Supervisors, made the following comment [taken from meeting video]: "Siskiyou county has identified declining deer populations. My grandchildren can't hunt deer because there's not enough of them here anymore. When we as the county supervisors took this before the department we 


\section{Issues in Information Systems \\ Volume 14, Issue 2, pp.156-165, 2013}

had citizens who were biologists that asked to be able to go out and count the number of deer in the winter areas. Your department declined that as not valid data, that the data had to come from the department before you would consider it [11]."

Table 2: Use of the Internet by State Agencies for Deer Herd Management Survey in March and April of 2013

Explanation and Codes for Each Category

Harvest: Indicates if the state reports the total deer harvest and related information on their web site. Y for Yes, otherwise blank.

Detail: Indicates level of detail for harvest report with $\mathrm{H}$ for high; $\mathrm{M}$ for Medium; L for low.

Search: Indicates if the state provides an online searchable database of deer harvest information. Y for yes.

License: Indicates if the state sales deer hunting licenses online. Y for Yes, otherwise blank.

Report: Indicates if deer kill can be reported using the internet. Y for Yes, otherwise blank

Social: $\quad \mathrm{Y}$ indicates that the social media are used by the agency, otherwise blank.

\begin{tabular}{|c|c|c|c|c|c|c|c|c|c|c|c|c|c|c|c|c|c|c|c|c|c|c|c|c|c|}
\hline State: & $\begin{array}{l}\mathbf{A} \\
\mathbf{L}\end{array}$ & \begin{tabular}{l|}
$\mathbf{A}$ \\
$\mathbf{K}$
\end{tabular} & $\begin{array}{l}\mathbf{A} \\
\mathbf{Z}\end{array}$ & $\begin{array}{l}\mathbf{A} \\
\mathbf{R}\end{array}$ & $\begin{array}{l}\mathbf{C} \\
\mathbf{A}\end{array}$ & $\begin{array}{l}\text { C } \\
\text { O }\end{array}$ & $\begin{array}{l}\mathbf{C} \\
\mathbf{T}\end{array}$ & \begin{tabular}{l|}
$\mathbf{D}$ \\
$\mathbf{E}$
\end{tabular} & $\begin{array}{l}\mathbf{F} \\
\mathbf{L}\end{array}$ & $\begin{array}{l}\mathbf{G} \\
\mathbf{A}\end{array}$ & \begin{tabular}{|l|}
$\mathbf{H}$ \\
$\mathbf{I}$
\end{tabular} & \begin{tabular}{l|}
$\mathbf{I}$ \\
$\mathbf{D}$
\end{tabular} & $\begin{array}{l}\mathbf{I} \\
\mathbf{L}\end{array}$ & $\begin{array}{l}\mathbf{I} \\
\mathbf{N}\end{array}$ & $\begin{array}{l}\mathbf{I} \\
\mathbf{A}\end{array}$ & $\begin{array}{l}\mathbf{K} \\
\mathbf{S}\end{array}$ & $\begin{array}{l}\mathbf{K} \\
\mathbf{Y}\end{array}$ & $\begin{array}{l}\mathbf{L} \\
\mathbf{A}\end{array}$ & \begin{tabular}{|l|}
$\mathbf{M}$ \\
$\mathbf{E}$
\end{tabular} & $\begin{array}{l}\mathbf{M} \\
\mathbf{D}\end{array}$ & $\begin{array}{l}\mathbf{M} \\
\mathbf{A}\end{array}$ & $\begin{array}{l}\mathbf{M} \\
\mathbf{I}\end{array}$ & $\begin{array}{l}\mathbf{M} \\
\mathbf{N}\end{array}$ & $\begin{array}{l}\mathbf{M} \\
\mathbf{S}\end{array}$ & $\begin{array}{l}\mathbf{M} \\
\mathbf{O}\end{array}$ \\
\hline Harvest & $\mathrm{Y}$ & $\mathrm{Y}$ & $\mathrm{Y}$ & $\mathrm{Y}$ & & $\mathrm{Y}$ & $\mathrm{Y}$ & $\mathrm{Y}$ & $\mathrm{Y}$ & $\mathrm{Y}$ & & $\mathrm{Y}$ & $\mathrm{Y}$ & $\mathrm{Y}$ & $\mathrm{Y}$ & & $\mathrm{Y}$ & $\mathrm{Y}$ & $\mathrm{Y}$ & $\mathrm{Y}$ & $\mathrm{Y}$ & $\mathrm{Y}$ & $\bar{Y}$ & $\mathrm{Y}$ & $\mathrm{Y}$ \\
\hline Detail & $\mathrm{L}$ & $\mathrm{H}$ & $\mathrm{H}$ & $\mathrm{H}$ & $\mathrm{M}$ & $\mathrm{H}$ & $\mathrm{H}$ & $\mathrm{H}$ & $\mathrm{M}$ & $\mathrm{L}$ & & $\mathrm{H}$ & $\mathrm{H}$ & $\mathrm{H}$ & $\mathrm{H}$ & & $\mathrm{H}$ & $\mathrm{H}$ & $\mathrm{H}$ & $\mathrm{H}$ & $\mathrm{H}$ & $\mathrm{H}$ & $\mathrm{H}$ & $\mathrm{H}$ & $\mathrm{H}$ \\
\hline Search & & Y & & $\mathrm{Y}$ & & & & & & & & $\mathrm{Y}$ & & $\mathrm{Y}$ & $\mathrm{Y}$ & & $\mathrm{Y}$ & & & & & & & & $\mathrm{Y}$ \\
\hline License & $\mathrm{Y}$ & $\bar{Y}$ & $\mathrm{Y}$ & $\mathrm{Y}$ & $\mathrm{Y}$ & Y & $\mathrm{Y}$ & $\mathrm{Y}$ & $\mathrm{Y}$ & $\mathrm{Y}$ & $\bar{Y}$ & $\mathrm{Y}$ & $\mathrm{Y}$ & $\mathrm{Y}$ & $\mathrm{Y}$ & \begin{tabular}{|c|}
$\mathrm{Y}$ \\
\end{tabular} & $\mathrm{Y}$ & $\mathrm{Y}$ & $\mathrm{Y}$ & $\mathrm{Y}$ & $\mathrm{Y}$ & $\mathrm{Y}$ & $\mathrm{Y}$ & $\mathrm{YY}$ & $\mathrm{Y}$ \\
\hline Report & $\mathrm{Y}$ & $\mathrm{Y}$ & $\mathrm{Y}$ & & $\mathrm{Y}$ & & $\mathrm{Y}$ & $\mathrm{Y}$ & & & & & $\mathrm{Y}$ & $\mathrm{Y}$ & $\mathrm{Y}$ & $\mathrm{Y}$ & & $\mathrm{Y}$ & & $\mathrm{Y}$ & $\mathrm{Y}$ & $\mathrm{Y}$ & $\mathrm{Y}$ & $\mathrm{Y}$ & $\mathrm{Y}$ \\
\hline \multicolumn{26}{|l|}{ Social } \\
\hline FaceBook & $\mathrm{Y}$ & & Y & $\mathrm{Y}$ & $\mathrm{Y}$ & $\mathrm{Y}$ & $\mathrm{Y}$ & & $\mathrm{Y}$ & \begin{tabular}{l|l}
$\mathrm{Y}$ \\
\end{tabular} & $\bar{Y}$ & & $\mathrm{Y}$ & $\mathrm{Y}$ & $\mathrm{Y}$ & \begin{tabular}{|l|}
$\mathrm{Y}$ \\
\end{tabular} & $\mathrm{Y}$ & $\mathrm{Y}$ & $\mathrm{Y}$ & $\mathrm{Y}$ & & $\mathrm{Y}$ & $\mathrm{Y}$ & $\mathrm{Y}$ & $\mathrm{Y}$ \\
\hline Twitter & $\mathrm{Y}$ & & $\mathrm{Y}$ & $\mathrm{Y}$ & $\mathrm{Y}$ & $\mathrm{Y}$ & & $\mathrm{Y}$ & $\mathrm{Y}$ & $\mathrm{Y}$ & $\overline{\mathrm{T}}$ & $\mathrm{Y}$ & $\mathrm{Y}$ & $\mathrm{Y}$ & $\mathrm{Y}$ & \begin{tabular}{|c|}
$\mathrm{Y}$ \\
\end{tabular} & & $\mathrm{Y}$ & \begin{tabular}{|l|}
$\mathrm{Y}$ \\
\end{tabular} & $\mathrm{Y}$ & $\mathrm{Y}$ & $\mathrm{Y}$ & $\mathrm{Y}$ & $\mathrm{YY}$ & $\mathrm{Y}$ \\
\hline YouTube & $\mathrm{Y}$ & & & & $\mathrm{Y}$ & $\mathrm{Y}$ & & & $\mathrm{Y}$ & $\mathrm{Y}$ & $F$ & $\mathrm{Y}$ & $\mathrm{Y}$ & $\mathrm{Y}$ & $\mathrm{Y}$ & & & $\mathrm{Y}$ & $\mathrm{Y}$ & & & $\mathrm{Y}$ & $\mathrm{Y}$ & & $\mathrm{Y}$ \\
\hline Flickr & & & & $\mathrm{Y}$ & $\mathrm{Y}$ & & & & $\mathrm{Y}$ & & & & & & & & & & $\mathrm{Y}$ & & $\mathrm{Y}$ & & & & $\mathrm{Y}$ \\
\hline Google + & & & & $\mathrm{Y}$ & & & & & $\mathrm{Y}$ & & & & & & & & & & & $\mathrm{Y}$ & & & & & \\
\hline RSS & & & $\mathrm{Y}$ & & $\mathrm{Y}$ & & & $\mathrm{Y}$ & $\mathrm{Y}$ & & & & & $\mathrm{Y}$ & $\mathrm{Y}$ & $\mathrm{Y}$ & & & & & & $\mathrm{Y}$ & $\mathrm{Y}$ & & $\mathrm{Y}$ \\
\hline & & & & & & & & & & & & & & & & & & & & & & & & & \\
\hline \multirow[t]{2}{*}{ State: } & $\mathbf{M}$ & \begin{tabular}{l|l}
$\mathbf{N}$ \\
\end{tabular} & $\mathbf{N}$ & $\mathbf{N}$ & $\mathbf{N}$ & $\mathbf{N}$ & $\mathbf{N}$ & $\mathbf{N}$ & $\mathbf{N}$ & $\mathbf{O}$ & \begin{tabular}{l|l}
$\mathbf{O}$ & \\
\end{tabular} & \begin{tabular}{l|}
$\mathbf{O}$ \\
\end{tabular} & $\mathbf{P}$ & $\mathbf{R}$ & $\mathbf{S}$ & $\mathbf{S}$ & \begin{tabular}{|l|}
$\mathbf{T}$ \\
\end{tabular} & $\mathbf{T}$ & $\overline{\mathbf{U}}$ & $\mathbf{V}$ & $\mathbf{V}$ & $\mathbf{W}$ & $\mathbf{W}$ & \begin{tabular}{l|l}
$\mathbf{W}$ \\
\end{tabular} & $\overline{\mathbf{W}}$ \\
\hline & $\mathbf{T}$ & $\mathbf{E}$ & $\mathbf{V}$ & $\mathbf{H}$ & $\mathbf{J}$ & $\mathbf{M}$ & $\mathbf{Y}$ & $\mathbf{C}$ & D & $\mathbf{H}$ & $\mathbf{K}$ & $\mathbf{R}$ & $\mathbf{A}$ & I & $\mathbf{C}$ & $\mathbf{D}$ & $\mathbf{N}$ & $\mathbf{X}$ & $\mathbf{T}$ & $\mathbf{T}$ & $\mathbf{A}$ & $\mathbf{A}$ & $\mathbf{V}$ & I & $\mathbf{Y}$ \\
\hline Harvest & $\mathrm{Y}$ & $\mathrm{Y}$ & $\mathrm{Y}$ & $\mathrm{Y}$ & $\mathrm{Y}$ & $\mathrm{Y}$ & $\mathrm{Y}$ & $\mathrm{Y}$ & & $\mathrm{Y}$ & $\mathrm{Y}$ & $\mathrm{Y}$ & $\mathrm{Y}$ & $\mathrm{Y}$ & $\mathrm{Y}$ & $\mathrm{Y}$ & $\mathrm{Y}$ & $\mathrm{Y}$ & $\mathrm{Y}$ & $\mathrm{Y}$ & $\mathrm{Y}$ & $\mathrm{Y}$ & $\mathrm{Y}$ & $\mathrm{Y}$ & $\mathrm{Y}$ \\
\hline Detail & $\mathrm{H}$ & $\mathrm{M}$ & $\mathrm{H}$ & $\mathrm{H}$ & $\mathrm{M}$ & $\mathrm{M}$ & $\mathrm{H}$ & $\mathrm{H}$ & & $\mathrm{H}$ & $\mathrm{M}$ & $\mathrm{H}$ & $\mathrm{H}$ & $\mathrm{H}$ & $\mathrm{H}$ & $\mathrm{H}$ & $\mathrm{H}$ & $\mathrm{H}$ & $\mathrm{H}$ & $\mathrm{H}$ & $\mathrm{H}$ & $\mathrm{H}$ & $\mathrm{H}$ & $\mathrm{H}$ & $\mathrm{H}$ \\
\hline Search & $\mathrm{Y}$ & & & & & & & & & & & & & & & & $\mathrm{Y}$ & & & & $\mathrm{Y}$ & & & & \\
\hline License & $\mathrm{Y}$ & $\mathrm{Y}$ & $\mathrm{Y}$ & $\mathrm{Y}$ & $\mathrm{Y}$ & $\mathrm{Y}$ & $\mathrm{Y}$ & $\mathrm{Y}$ & $\mathrm{Y}$ & $\mathrm{Y}$ & $\mathrm{Y}$ & $\mathrm{Y}$ & $\mathrm{Y}$ & $\mathrm{Y}$ & $\mathrm{Y}$ & $\mathrm{Y}$ & $\mathrm{Y}$ & $\mathrm{Y}$ & $\mathrm{Y}$ & $\mathrm{Y}$ & $\mathrm{Y}$ & $\mathrm{Y}$ & $\mathrm{Y}$ & $\mathrm{Y}$ & $\mathrm{Y}$ \\
\hline Report & $\mathrm{Y}$ & & & & $\mathrm{Y}$ & $\mathrm{Y}$ & $\mathrm{Y}$ & $\mathrm{Y}$ & & $\mathrm{Y}$ & $\mathrm{Y}$ & $\mathrm{Y}$ & $\mathrm{Y}$ & & & & $\mathrm{Y}$ & & & & $\mathrm{Y}$ & $\mathrm{Y}$ & & & \\
\hline \multicolumn{26}{|l|}{ Social } \\
\hline FaceBook & & $\mathrm{Y}$ & $\mathrm{Y}$ & $\mathrm{Y}$ & & $\mathrm{Y}$ & & $\mathrm{Y}$ & & $\mathrm{Y}$ & $\mathrm{Y}$ & $\mathrm{Y}$ & $\mathrm{Y}$ & & $\mathrm{Y}$ & $\mathrm{Y}$ & $\mathrm{Y}$ & $\mathrm{Y}$ & $\mathrm{Y}$ & $\mathrm{Y}$ & & $\mathrm{Y}$ & & $\mathrm{Y}$ & $\mathrm{Y}$ \\
\hline Twitter & $\mathrm{Y}$ & $\mathrm{Y}$ & $\mathrm{Y}$ & & & $\mathrm{Y}$ & & $\mathrm{Y}$ & & $\mathrm{Y}$ & $\mathrm{Y}$ & $\mathrm{Y}$ & $\mathrm{Y}$ & & $\mathrm{Y}$ & $\mathrm{Y}$ & $\mathrm{Y}$ & $\mathrm{Y}$ & $\mathrm{Y}$ & & & $\mathrm{Y}$ & & $\mathrm{Y}$ & $\mathrm{Y}$ \\
\hline YouTube & & $\mathrm{Y}$ & & $\mathrm{Y}$ & & $\mathrm{Y}$ & & $\mathrm{Y}$ & & $\mathrm{Y}$ & & $\mathrm{Y}$ & $\mathrm{Y}$ & & $\mathrm{Y}$ & $\mathrm{Y}$ & $\mathrm{Y}$ & $\mathrm{Y}$ & $\mathrm{Y}$ & & & $\mathrm{Y}$ & & $\mathrm{Y}$ & $\mathrm{Y}$ \\
\hline Flickr & & & & & & & & $\mathrm{Y}$ & & & & & & & & & & $\mathrm{Y}$ & & & & & & $\mathrm{Y}$ & \\
\hline Google + & & & $\mathrm{Y}$ & & & & & $\mathrm{Y}$ & & & & & & & & & & & & & & & & & \\
\hline RSS & $\mathrm{Y}$ & $\mathrm{Y}$ & & & & & & & & & & $\mathrm{Y}$ & & & $\mathrm{Y}$ & & & & & & $\mathrm{Y}$ & $\mathrm{Y}$ & $\mathrm{Y}$ & $\mathrm{Y}$ & \\
\hline
\end{tabular}

\section{VISUALIZING TRENDS IN THE CALIFORNIA DEER POPULATION}

What do the people of the state of California see when they type the phrase "California Deer Population" into Google search? Near or at the top of the search list is this graphic, Figure 1 below (public domain), from the California Fish and Wildlife Website. In reading some supporting information of a more detailed version of the graph, it appears this information was created in the mid-1990s. The webpage provides the following explanation 


\section{Issues in Information Systems \\ Volume 14, Issue 2, pp.156-165, 2013}

of the vertical axis: "Abundant" refers to deer populations of 700,000-1,000,000; "Common" refers to deer populations between 400,000-700,000; and "Scarce" refers to populations lower than 400,000 animals [7]."

Figure 1: Trends in California Deer Numbers in Relation to Habitat Quality

Graphic from California Department of Fish and Wildlife Website

(April, 2013. Public Domain)

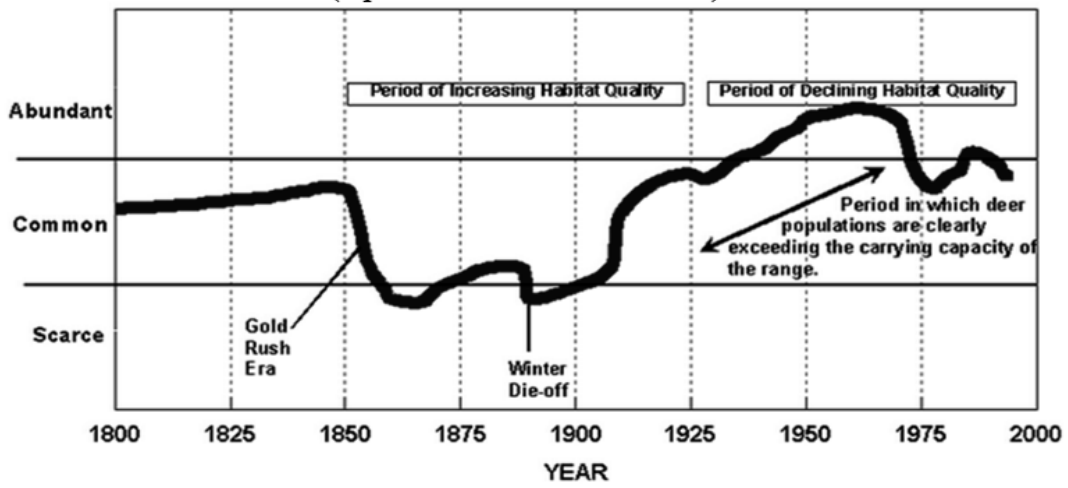

The reliability of the information in Figure 1 was tested by overlaying other population estimates discovered using the internet data mining. According to recent online news stories including one written by Tom Stienstra, perhaps California's most prominent outdoors reporter, peak deer population was in the early 1960s and was estimated at about 2 million [16] with other estimates at 1.5 to 2 million. As Figure 2 illustrates the comparison of the data sources results in two very different pictures of the trend in the California deer population.

Figure 2: Overlay of Population Data Based on Estimates from

Individual Years of about 1960 from News Reports and

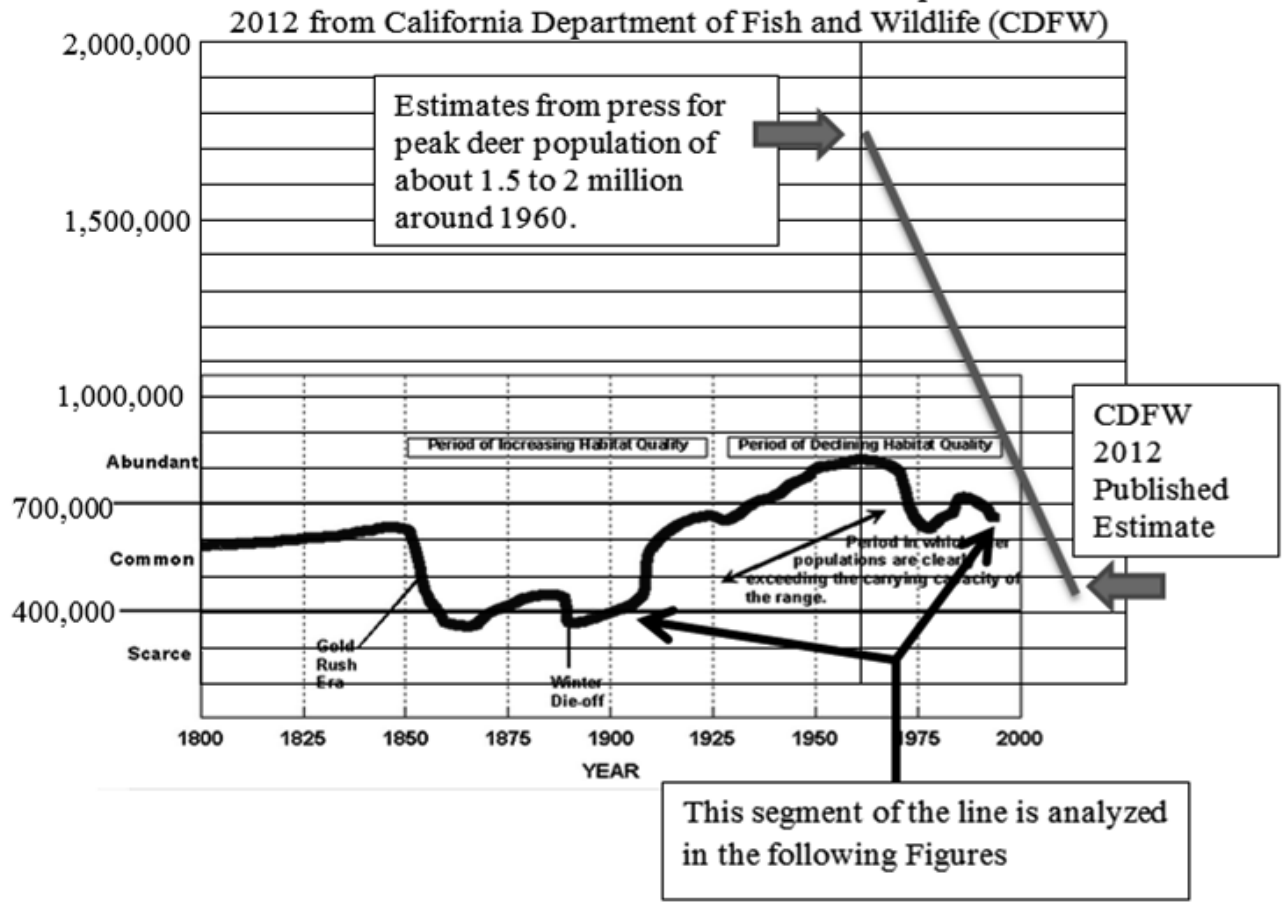

Figure 3 overlays the California population estimate from Figure 1 for about 1917 to 1995 against the total reported deer kill from hunting which is expected to approximately track with the population trend. Clearly the trends do not match. Possible explanations for the difference in these two trends are discussed in the next section. 


\section{Issues in Information Systems \\ Volume 14, Issue 2, pp.156-165, 2013}

Figure 3: California Deer Harvest (Total Reported Kill) from 1911 to 2012, Overlaid against CDFW Population Estimate (Solid Line) from Figure 1

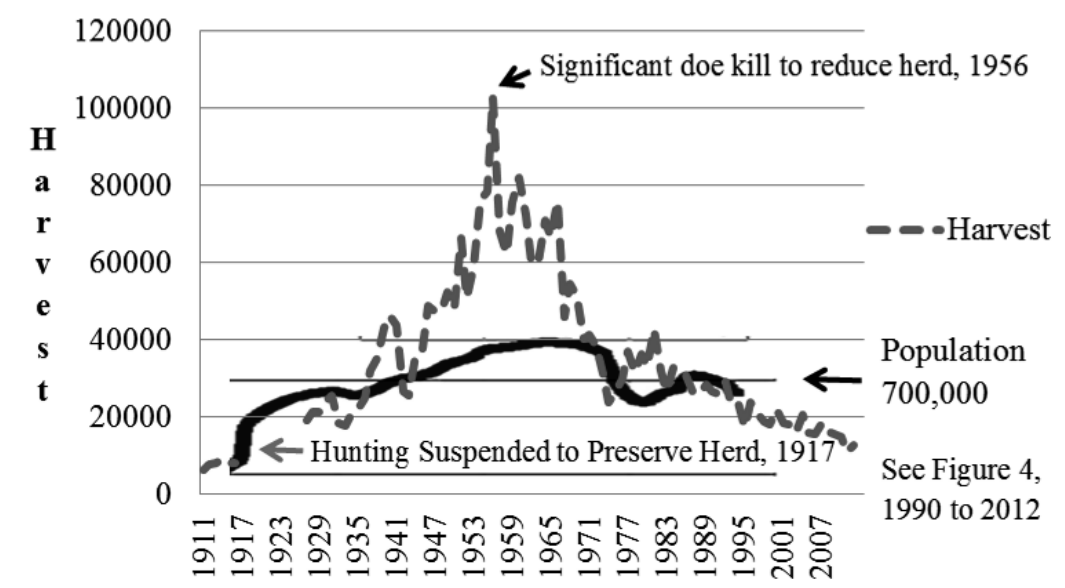

\section{TESTING THE DIFFERENCE IN THE RATIO OF THE DEER KILL (HARVEST BY HUNTING) TO THE POPULATION OVER TIME}

Although there has been no census of the California deer population, the California Department of Fish and Game published a study by William M. Longhurst. Aldo Leopold, and other researchers with an estimate of the California deer population for 1947: 1,123,000 deer. They make this comment: “...The actual population of deer in California ... is probably considerably above our figure [12]." His group relied heavily on the reported deer kill for the year, a total of 47,059, a slightly different number than we see in the historical data currently available on the department's website showing a total of 47,416. The Longhurst group calculates an estimated deer kill of about 75,000, comparable to current estimated differences between the reported and estimated deer kill (some hunters don't report their kill). Historical statistics show no doe kills reported in California in 1947. Commenting on their method "Use of deer kill statistics as a basis for estimating populations has a long history in wildlife management and has been a standard practice in many states... Where sex ratio counts are available in combination with deer kill figures, accurate estimates of populations are possible... For most areas in California only the kill figures were available [13]." Except for 1955 and more significantly in 1956, the doe kill has generally been small or zero in California, averaging 2.3 percent of the total kill and in the range of 0 to 8.4 percent. The sex ratio of the deer kill has generally been about the same.

Longhurst's group estimated that the reported kill in 1947 was 4.22 percent of the population. Figure 4 provides a graph of current population estimates from the California Fish and Wildlife and the reported deer kill (harvest) for 1990 to 2012. Since these population estimates do not appear on the California Fish and Wildlife website, the data analysis described in this section was originally based on a graph created by the Sacramento Bee illustrating data provided to them by Fish and Wildlife. After sending a letter to the California Game Commission through the formal public input process with information similar to Figure 2 showing the divergence of the reported kill and population estimates, we received their numerical population estimates from 1990 to 2012. By comparing the population estimates derived from overlaying a grid on a digitized image of the graph from the newspaper with the actual data from the Department of Fish and Wildlife, an average mean absolute percentage error for each year of only 0.61 percent was calculated. This is encouragingly close since search often discovers data available only in graphic, not numeric form.

During 2011 there were numerous reports in the local press identified through the internet data mining process that the deer population in California was being "hammered." As Figure 4 suggests, there was a significant decline in the deer harvest that year. 


\section{Issues in Information Systems}

Volume 14, Issue 2, pp.156-165, 2013

Figure 4: California Estimated Deer Population and Reported Harvest, 1990 to 2012

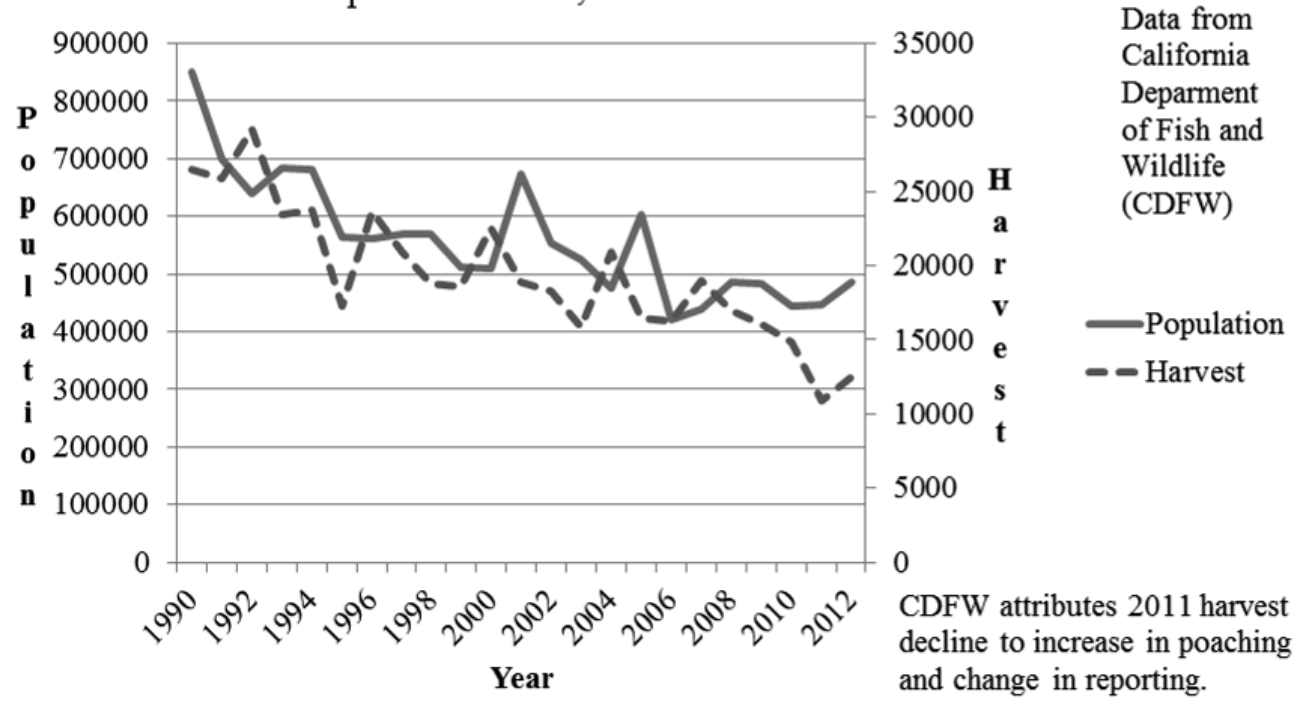

Although as of this writing, the 2012 harvest data has not been published on the Fish and Wildlife website, the internet data mining discovered that data from the state that had been posted on a California bow hunting discussion site so this number was used for 2012. Preliminary 2011 data is on the California Department of Fish and Wildlife site, but there are apparently different numbers floating around for this year. We took the 2011 data from a report given to the Game Commission in 2012 and shared with us by a fellow researcher. The rest of the deer harvest data in the graph were taken from the Fish and Wildlife website. There were a few small discrepancies in the historical data as numbers are no doubt revised somewhat in later years to reflect new information. The 2011 to 2012 harvest data is therefore approximate so is not used in the analysis that follows.

Over the 1990 to 2012 period represented in Figure 4 and even going back to the 1960s, the sex distribution of the harvest has changed very little. Few does are killed and the buck to doe ratio has been targeted to be in the 25 or 30 to 100 range. Both policies are designed to produce the highest sustainable harvest. Yet, something has gone wrong in California where the annual harvest has been on a downward trend since the 1960s. The divergence of the kill to population ratio beginning in about 2008 also signals a potential problem. The California Department of Fish and Wildlife estimates that the deer population has increased by 15.4 percent since 2006, but the deer harvest has declined by about 22.3 percent. The discrepancy between harvest and the population estimate is particularly evident in the recent years when no final data has been reported to the public. The agency suggests that a change in reporting rates and an increase in poaching accounts for the decline [6]. The internet data mining has discovered no other state reporting a significant increase in poaching.

The common explanation provided for the divergence of the estimated historic population in Figure 1 and the historic reported kill has been that the reporting ratio has changed. A formal hypothesis test of the difference between the 1947 reporting ratio estimated by Longhurst and the average current ratio can be formulated as:

$\mathrm{H}_{1}$ : The ratio $(\mathrm{R})$ of the reported kill to the total population is different in 1947 than the average for the 1990 to 2010 period; $\mathrm{R}_{1947} \neq \mathrm{R}_{1990}$ to 2010

Table 3 summarizes the results of the test and provides some descriptive statistics. If the 0.0422 kill to population ratio based on Longhurst's estimate for the 1947 herd is applied to the kill data for all years, peak population in California would have occurred in 1956 with a population of about 2,432,133. However, in 1955 and particularly in 1956 the sex ratio of the harvest changed somewhat with a large number of does being killed to control the population. Ignoring these years, the peak population would be in 1960 at 1,946,967 or 1,782,891 without counting the doe kill. This population estimate is consistent with the press reports illustrated in Figure 2 of 1.5 to 2 million deer peak population in the early 1960s. 


\section{Issues in Information Systems \\ Volume 14, Issue 2, pp.156-165, 2013}

Table 3: Descriptive Statistics for the Average Reported Kill to Population Ratio, 1990 to 2010, and a Comparison of this Average to the Estimated Ratio for 1947 in the Longhurst Study $\left(\mathrm{R}_{1947}=0.0422\right)$

\begin{tabular}{|c|c|}
\hline \multicolumn{2}{|l|}{$\begin{array}{l}\text { Descriptive Statistics, Reported Kill to } \\
\text { Population, } 1990 \text { to } 2010\end{array}$} \\
\hline $\begin{array}{l}\text { Average Reported Kill to Population: } \\
\qquad \mathrm{R}_{1910 \text { to } 2010}\end{array}$ & 0.0358 \\
\hline Standard Deviation & 0.00543 \\
\hline Range & 0.0273 to 0.0456 \\
\hline \multicolumn{2}{|l|}{ Results of Hypothesis test } \\
\hline $\begin{array}{r}\mathrm{H}_{\mathrm{o}}: \mathrm{R}_{1947}=\mathrm{R}_{1990 \text { to } 2010 \text { t-statistic: }} \\
\mathrm{H}_{\mathrm{o}} \text { : The Ratios Are the Same (rejected) }\end{array}$ & -5.412 \\
\hline Significance (2-tailed) & 0.000 \\
\hline Degrees of Freedom & 20 \\
\hline Mean Difference & -0.00641 \\
\hline $95 \%$ Confidence Interval of the Difference & $\begin{array}{l}\text { Lower: }-0.0089 \\
\text { Upper: }-0.0039\end{array}$ \\
\hline \multicolumn{2}{|c|}{$\begin{array}{l}\text { Conclusion: The difference is significant with a p-value less than } .01 \text {. The } \\
\text { difference is about half a percent }(0.00641) \text { with a } 95 \text { percent confidence } \\
\text { interval of about plus or minus } 0.0025 \text {. The } 1947 \text { ratio of } 0.0422 \text { is within the } \\
\text { range of the } 1990 \text { to } 2010 \text { ratios, below the } 1992 \text { ratio of } 0.0456 \text {. The } \\
\text { researchers in the Longhurst study commented that they suspected their } \\
\text { population estimate was too low, if so the ratios might be the same. }\end{array}$} \\
\hline
\end{tabular}

In order to give a range of feasible population estimates, deer populations using the range of kill to population ratios from Table 3, with and without does included in the reported kill, are reported in Table 4. These ratios include the current average ratio based on the 1990 to 2010 data, the high and low ratios for the 1990 to 2010 period, and the Longhurst ratio.

Table 4: Peak California Deer Populations Using Different Assumptions for Ratio of Reported Kill to Population and Sex of Deer

\begin{tabular}{|l|l|l|}
\hline Assumption for Ratio of Reported Kill to Population, and Sex of Deer & $\begin{array}{l}\text { Peak } \\
\text { Year }\end{array}$ & $\begin{array}{l}\text { Estimated } \\
\text { Population }\end{array}$ \\
\hline $\begin{array}{l}\text { Longhurst Ratio: Reported deer kill is 0.0422 of population } \\
\quad \text { Without high doe kill year of 1956 }\end{array}$ & 1956 & $2,432,133$ \\
Longhurst Ratio applied to bucks: Reported buck kill is 0.0422 of population & 1960 & $1,946,967$ \\
\hline $\begin{array}{l}\text { Average 1990-2010 Ratio: Reported deer kill is 0.0358 of the population, current } \\
\text { average from the California Department of Fish and Wildlife for 1990 to 2010 }\end{array}$ & 1960 & $1,782,891$ \\
$\quad \begin{array}{l}\text { Without high doe kill year of 1956 } \\
\text { Average 1990-2010 Ratio applied to bucks: Reported buck kill is 0.0358 of population }\end{array}$ & 1960 & $2,866,927$ \\
\hline $\begin{array}{l}\text { Low 1990-2010 Ratio. Reported deer kill is 0.0273 of the population, bottom of the } \\
\text { range from California Department of Fish and Wildlife for 1990 to 2010 }\end{array}$ & 1956 & $2,295,028$ \\
$\quad \begin{array}{l}\text { Without high doe kill year of 1956 } \\
\text { Low 1990-2010 Ratio applied to bucks: Reported buck kill is 0.0273 of the population }\end{array}$ & 1960 & $1,801,799$ \\
\hline $\begin{array}{l}\text { High 1990-2010 Ratio. Reported deer kill is 0.0456 of population, the top of the range } \\
\text { from California Department of Fish and Wildlife for 1990 to 2010 }\end{array}$ & 1956 & $1,649,956$ \\
$\quad$ Without high doe kill year of 1956 & 1960 & $3,759,560$ \\
High 1990-2010 Ratio applied to bucks: Reported buck kill is 0.0456 of population & 1960 & $2,755,971$ \\
\hline
\end{tabular}

Ignoring the high doe kill years around 1956, the population estimates reported in Table 4 range from 1,649,956 to $3,009,597$. The results suggest that the deer population estimates discovered in the online news articles appear to be approximately correct, perhaps a bit conservative. The graphic presented by the Department of Fish and Wildlife (Figure 1) is contradicted by its own study conducted by Longhurst, as illustrated in Figure 5 which compares the graphic from the Department of Fish and Wildlife to the Longhurst estimate and illustrates the range of population estimates based on the historic range of the kill to population ratio. 


\section{Issues in Information Systems \\ Volume 14, Issue 2, pp.156-165, 2013}

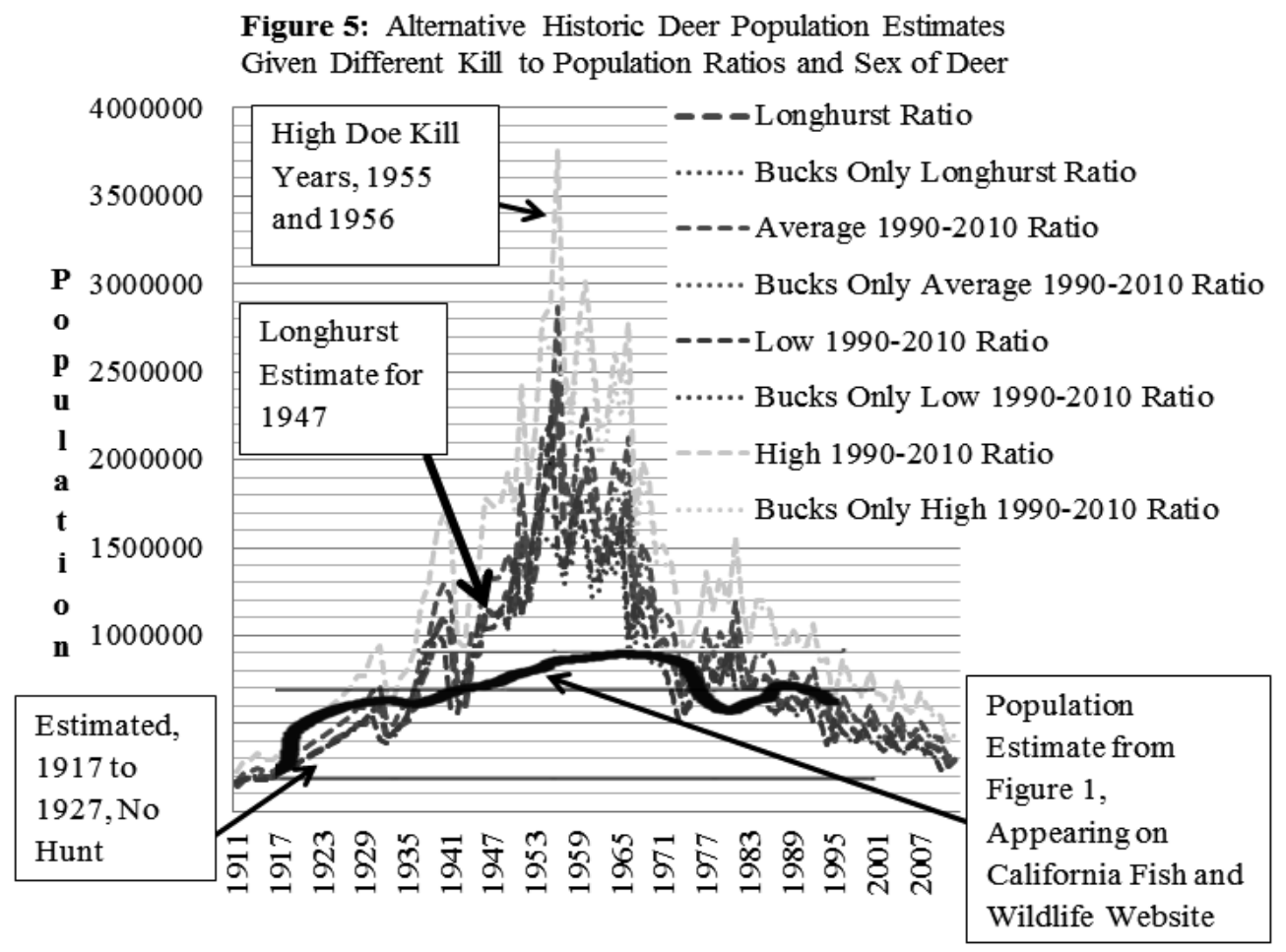

CONCLUSIONS

Through simple data mining of the Internet, the research identified some important issues related to public management of deer in California. Like other states, California has recently invested in an online hunting license sales system, but it is the only state identified by the survey that has reduced the amount of deer harvest data that it reports to the public on its web site. The graph on the Department of Fish and Wildlife website depicting the long term population trend appears to significantly understate the decline of the deer population, recent population estimates showing the significant decline since 1990 are not presented to the public on the website, and the population estimates since about 2008 diverge from the underlying harvest data which suggests a continuing population decline. Population levels appear to be approaching historic low levels when hunting was suspended to preserve the people's deer herd, but selling deer hunting tags is a significant source of revenue for the department.

Without complex algorithms, significant discovery was made using freely available search tools. The resulting information has been used to design and build an online decision support site that has provided some public utility. Organizations may find that this approach can be easily applied to other topics of interest. The data mining process has also identified some interesting hypotheses as to the cause of the decline of California's deer population that will be the basis for future research. Other researchers have used this approach to generate ideas, hypotheses, and data for their own research.

\section{REFERENCES}

1. Astani, M., Elhindi, M., (2008). An empirical study of university websites. Issues in Information Systems, 9(2), $460-465$

2. Bassett, R., Chamberlain, T., Cunningham, S., Vidmar, G., (2010). Data mining and social networking sites: protecting business infrastructure and beyond. Issues in Information Systems, 11(1), 353

3. Bhadoria, R.S., Dixit, M., Bansal, R., Chauhan, A.S. (2012). Detecting and searching system for event on internet blog data using cluster mining. Proceedings of the International Conference on Information Systems Design and Intelligent Applications, 132, p. 83.

4. Bun, K.K. (2001). Emerging topic tracking system. Advanced Issues of E-Commerce and Web-Based Information Systems, WECWIS 2001, Third International Conference, 2-11 


\section{Issues in Information Systems}

Volume 14, Issue 2, pp.156-165, 2013

5. Boggs, R.A. \& Walters, D. (2006). A longitudinal look at e-government in practice. Issues in Information Systems, 7(2), 161-164

6. California Department of Fish and Game (2012). California Big Game Hunting, p. 21 Available: http://www.dfg.ca.gov/publications/digest/

7. California Department of Fish and Game Website, April, 2013. Available: http://www.dfg.ca.gov/wildlife/hunting/deer/population.html

8. DeLong, J. (2012) Hunters, wildlife officials lock horns over whether Nevada mule deer are over-harvested RGJ.com, October 27. Available at: http://www.rgj.com/article/20121028/LIV08/310280052/Hunters-wildlifeofficials-lock-horns-over-whether-Nevada-mule-deer-herds-overharvested?gcheck=1

9. Huang, Z. (2006). E-government practices at local levels: An analysis of U.S. counties' websites. Issues in Information Systems, 7(2), 165-170.

10. Jockers, L.M., Sag, M., \& Schultz, J., (2012). Digital archives: Don’t let copyright block data mining. Nature, 490, 29-30

11. Kobseff, M. (2013) Testimony before the California Game Commission, March 6, 2013 on topic 8 "Consideration of Whether Listing Clear Lake Hitch under CESA may be Warranted" available: http://www.fgc.ca.gov/meetings/2013/030613videolinks.aspx

12. Longhurst, W.M., Leopold, A.S., Dasmann, R.F., (1952) A survey of California deer herds: their ranges and management problems. California Department of Fish and Game, Bureau of Game Commission, Game Bulletin, No. 6. p. 30.

13. Longhurst, W.M., Leopold, A.S., Dasmann, R.F., (1952) A survey of California deer herds: their ranges and management problems. California Department of Fish and Game, Bureau of Game Commission, Game Bulletin, No. 6. p. 27.

14. MacLean, D., Seltzer, M.I., (2011). Mining the Web for medical hypotheses: A proof-of-concept system. Proceedings of the 2011 International Conference on Health Informatics. Available: http://dash.harvard.edu/handle/1/8739094

15. Ramasamy, M. (2007). On the dimension of e-government interactions. Issues in Information Systems, $8(2), 146-151$

16. Stienstra, T. (2013) Fawns are food for predators in 2013. San Francisco Chronicle, April 14. Available: http://www.sfchronicle.com/outdoors/article/Fawns-are-food-for-predators-in-2013-4432952.php

17. Timo, W., Taylor, S., Walland, P., Geana, R., Weichselbaum, R., Fernandez, M., Sizov, S., (2012). Determining citizen's opinions about stories in news media: analyzing Google, Facebook, and Twitter. Journal of Democracy and Open Government, 4(2), 198-220.

18. Tsytsarau, M., Palpanas, T. (2012). Survey on mining subjective data on the web. Data Mining Knowledge Discovery, 24, p. 495

19. Westerfeld, C. (1916). Game Conditions in Great Britain vs. Conditions in California. California Fish and Game, V, 2

20. Wu, Yu-Chieh (2012). A template independent method for large online news content extraction. Advanced Applied Informatics, International Conference, p. 254-257.

21. Xiang, G., Zheng, Z., Wen, M., Hong, J., Liu, C. (2012). A supervised approach to predict company acquisition with factual and topic features using profiles and news articles on tech crunch. Proceedings of the Sixth International AAAI Conference on Weblogs and Social Media, p. 607

22. Yoon, J. (2012). Detecting weak signals for long-term business opportunities using text mining of Web news. Journal of Expert Systems with Applications, 39(16), 12543

23. Zhao, J.J. Technology content analysis of the Fortune 500 corporate web sites. Issues in Information Systems, 769-775

24. Zhao, J.J., Truell, A.D., Alexander, M.W., Davis, R., (2006). State e-government service and economic competitiveness: A relational issue. Issues in Information Systems, 7(2), 171-176

25. Zimmerman, M., Ntoutsi, I., Siddiqui, Z.F., Spiliopoulou, M., Kriegel, H. (2012). Discovering global and local bursts in a stream of news. Proceedings of the $27^{\text {th }}$ Annual ACM Symposium on Applied Computing, p. 807. 